Biografistyka Pedagogiczna

Year 5 (2020) No. 2

ISSN 2543-6112; e-ISSN 2543-7399

DOI: $10.36578 /$ BP.2020.05.27

Paweł Prüfer*

\title{
A Commentary on the Book Entitled The Life and Works of Father Janusz Mariański: A Biography Against a Background of Sociology (1940-2020)
}

Na marginesie książki Wokół życia i dzieła Księdza Janusza Mariańskiego. Biografia $z$ socjologia $w$ tle (1940-2020)

cientific endeavours can be of various natures and forms. This is also because the dynamics of the social world and the subjective creativity of people constantly stimulate each other, encouraging men to act in a dynamic reality. A researcher, an intellectual, a representative of a group of people undertaking reflection on the social world (sociologists belong to this group) is someone who - as Franco Ferrarotti notes - is able to understand the reality here and now, comprehending the quality and recognising the fundamental features of the moment in which they live and work. ${ }^{2}$ These competences, which are also requirements and challenges, are also - in some way - evaluated, and when it turns out that much has been achieved in this area, they also become the subject of great recognition and appreciation.

* Father dr hab. Paweł Prüfer (ORCID: OOOO-0003-36478068) - professor at the Academy of Jakub from Paradyż in Gorzów Wielkopolski, contact: paweljazz@o2.pl

1 Wokót życia i dzieła Księdza Janusza Mariańskiego. Biografia $z$ socjologia $w$ tle (19402020), (eds) Stanisław Fel, Mariusz Zemło, Lublin 2020.

2 F. Ferrarotti, Osservazioni sul lavoro intelettuale, Edizioni Solfanelli, Chieti 2016, p. 20. 
This applies to Father Professor Janusz Mariański and his achievements. Thanks to the cooperation of many people and various institutions, a jubilee book has been published, which describes the researcher's scientific achievements as consummately and precisely as possible. The publication consists of four chapters. Chapter one is devoted to the life, as well as the research, teaching and organisational activities of the jubilarian. Chapter two recalls exceptional events organised in honour of Father Professor Mariański, the promotion of his book and the ceremony awarding him an honorary doctorate. In chapter three, the authors present radio and press interviews with the jubilarian, as well as his reviews, expert opinions and memories. Finally, chapter four contains a bibliographic outline of the scientific and research achievements of the Polish sociologist. As can be easily deduced, the structure of this publication is only a synthetic outline and, in a certain sense, a necessarily narrowed picture because the figure of the jubilarian, his research activity and, above all, his exceptionally rich scientific output significantly exceed the size of one book volume. However, we are glad that this project has been planned and prepared in such a clear and logical manner.

The publication describes Professor Mariański's intense scientific, didactic and organisational life. What is clearly evident are his scientific achievements. Readers will certainly wonder how it is possible for one biography to contain so many substantive undertakings. It is fortunate that this biography has been prepared in various ways by several authors. This is an excellent technique to show the multi-faceted image of the researcher. Published books, scientific articles, collective works, book chapters, reviews and other scientific publications presented by various recipients and authors show the richness of achievements and the unconventional nature of research, which often 'materialise' in the form of publications. This is the case of this jubilarian and the way in which his scientific profile has been presented. This publication also includes various events which help outline and evaluate the author's scientific and research achievements.

Not every researcher, including a sociologist, is properly recognised by his (and not only) community, awarded an honorary doctorate and invited 
to a ceremony held in his honour. Father Professor Mariański enjoyed all these events, which are described in chapter two of this book. Certainly, an interesting supplement to this publication is the chapter in which many researchers assess and review the scientific achievements of the jubilarian. Some of these descriptions take the form of fully quoted texts. This publishing strategy has certainly further enriched the whole undertaking.

Reading the book allows for one more short reflection. Since Father Professor Mariański is primarily a sociologist of religion, readers of his scientific achievements in this field may be intellectually encouraged to refer to some associations related to this particular discipline. Here I will mention one such association.

Sociologists in particular are very familiar with the idea of the German classic and honourable representative of this field, Max Weber, who developed the concept of vocation (Beruf) and its relationship with the work ethic. The Italian sociologist of religion, Roberto Cipriani, concludes that this idea was fundamental to Weber. ${ }^{1}$ Religious context and faith can be the driving force and point of reference for an individual when performing their life tasks, including those purely measurable and temporal. The person treats them as important and thus carries them out with motivation, commitment and determination, derived from the supernatural potential. Emphasising the value of one's existence, life activity and performance of professional duties is, in a sense, fulfilling one's life vocation. Reading about Father Professor Mariański's scientific, popular science, didactic and organisational achievements and activities irresistibly evokes the Weberian idea and, more precisely, that which is related to a life's commitment and work, perceived through the prism of vocation and mission. Human experience suggests that faithfulness to this perspective not only brings a lot of personal satisfaction to the person involved in its implementation, but also translates into a measurable good, the beneficiaries of which become their happy recipients. In this case, these will be the many readers, scientific communities, groups and institutions that really want to learn, understand and transform the surrounding reality, particularly its religious and moral

3 R. Cipriani, Nuovo Manuale di Sociologia della Religione, Roma 2009, p. 99. 
dimension. This jubilee book is the appropriate complementary step that opens up and continues the impact of the aforementioned good which manifests itself in many ways.

\section{Literature}

Cipriani R., Nuovo Manuale di Sociologia della Religione, Roma 2009.

Ferrarotti F., Osservazioni sul lavoro intelettuale, Edizioni Solfanelli, Chieti 2016.

Wokół życia i dzieła Księdza Janusza Mariańskiego. Biografia $z$ socjologia $w$ tle (1940-2020), (eds) Stanisław Fel, Mariusz Zemło, Lublin 2020. 